\title{
CONSENSUS CONFERENCES - A CASE STUDY: PUBLIFORUM IN SWITZERLAND WITH SPECIAL RESPECT TO THE ROLE OF LAY PERSONS AND ETHICS*
}

(Accepted in revised form 10 8, 2006)

\begin{abstract}
This paper focuses on experiences from a case study dealing with the Swiss type of a consensus conference called "PubliForum" concerning "Genetic Technology and Nutrition" (1999). Societal and ethical aspects of genetically modified food meanwhile can be seen as prototypes of topics depending on the involvement of the public through a participatory process. The important role of the lay perspective in this field seems to be accepted in practice. Nevertheless, there is still some theoretical controversy about the necessity and democratic legitimacy of participatory processes in general, and especially about those dealing with technological or environmental problems (sustainable development) concerning society. From an ethical point of view, a lot of heterogeneous problems concerning contents and procedures of public participation can be pointed out, not only on the theoretical level but also in practice, e.g., concerning the communication process between laypersons and experts. The intention of our paper is to give hints and to clarify criteria that support the communication process leading to a dialog of autonomous citizens and which especially consider ethical aspects in the field. One important result is that there must be an orientation for all members of a consensus conference having clear rules and knowing their different roles that support transparency, credibility, and fairness of the whole procedure and a "good product": a substantial final document or citizens' report.
\end{abstract}

KEY WORDS: autonomy, consensus conferences, GM food, lay persons, publiForum

\section{INTRODUCTION}

Nowadays, consensus conferences ${ }^{1}$ have been well established in Western democracies, since this method had been developed in the 1980s especially to introduce participatory elements into the debate about societal effects and problems of gene technology in different fields. CCs are important tools in

* This paper presents results of the project Ethical Bio-TA Tools as funded by the European Commission, DG Research, under FP5, Quality of Life Programme.

${ }^{1}$ In the following we use the abbreviation $\mathrm{CC}$ for "consensus conferences." 
European participatory technology assessment (Joss and Belucci, 2002; Nielsen et al., 2005).

A very recent development in consultation of public views has been the first international European CC concerning new technologies and ethical problems in the field of applied and theoretical neuroscience: "Meeting of Minds European Citizens Deliberation on Brain Sciences." This two-year pilot project includes a European panel of 126 citizens from nine European countries (Belgium, Denmark, Germany, France, Italy, The Netherlands, Greece, United Kingdom, and Hungary). ${ }^{2}$ One aim of this CC-project was to deliver a contribution to the European integration process in a time when the European Union seemed to be in a crisis. Many citizens in several nations of the EU did not agree with different political decisions on the European level. This new dimension of CCs was seen as a new approach to include a broader public in the debate on future research, technological decision-making, and governance. Two among other problems in this international CC-project were how to establish multilingual communication between citizens and how to integrate different democratic cultures and political systems in Europe.

This is the background for a look at the experience with CCs in Switzerland, a multilingual country (German, French, and Italian) in the middle of Europe with a long democratic tradition. Switzerland has developed a very special democratic culture and system emphasizing participatory elements in a direct democracy. Since 1998, four consensus conferences, each called "PubliForum," have been successfully arranged in Switzerland. The use of the name "PubliForum" already indicates the high self-confidence of the Swiss citizens and also a special relation to the term "consensus," which is deliberately avoided in this term. But on the other hand, the public relevance of the project is stressed in its name. These Swiss CCs have been dealing with heterogeneous topics like electricity, GM-food, or new developments in biomedicine (organ transplantation, research on human beings) as similarly carried out in other countries. At first sight, one could think that the multilingual Swiss version of CC could be a kind of "little Europe," although Switzerland is not a member of the EU. But the concept of "PubliForum" does not serve as a European CC model, because Switzerland has special regional characteristics in its democratic culture and political system. Nevertheless, the Swiss long term experience with multilingual communication and public participation could be of interest for further CCs on the European level, last, but not least, when looking at the important role of laypersons in CCs and at several ethical aspects of their procedure and content.

\footnotetext{
${ }^{2}$ http://www.meetingmindseurope.org.
} 
The primary focus of this paper is on practical matters and experiences from a case study dealing with the Swiss PubliForum "Genetic Technology and Nutrition" documented in a citizens' report (PubliForum, 1999a) and in the media (PubliForum, 1999b). Societal and ethical aspects of genetically modified food meanwhile can be seen as prototypes of topics needing the involvement of the public by a participatory process (Frewer et al., 2004; Heeger and Brom, 2003; Skorupinski, 2003). The important role of the lay perspective in this field seems to be accepted in practice, although, nevertheless, new methods are necessary to "integrate public values more efficaciously into risk analysis processes" (Frewer et al., 2004: 1181). Nevertheless, there is still some theoretical controversy about the necessity and democratic legitimacy of participatory processes in general, especially dealing with technological or environmental problems (sustainable development) concerning society (Heinrich, 2005 and Gethmann, 2005; Korf, 2005 and Renn, 2005). In these contexts and in environmental politics, theoretical and political arguments pro and contra participatory processes are involved (Smith, 2003). Not only is the practical relevance of discourse ethics concerned, but from another viewpoint also the theoretical bases of different approaches of thinkers like Habermas, Apel, etc. (Böhler et al., 2003). Having in mind this theoretical background, this paper presents considerations concerning ideal and real elements of CCs (Skorupinski and Ott, 2000, 2001). With respect to this context, some Habermasian political aspects of citizens' participation in democracies and current political considerations on integrating democratization processes on the European level are taken into account (Habermas, 1996, 2001; Zittel, 2003).

Obviously, there exist a lot of heterogeneous problems concerning CC contents and procedures from an ethical point of view, not only on the theoretical level but also in practice, for instance if an organizer of a CC is looking for criteria and a definition of what a "real lay" is or if a moderator or facilitator of CCs tries to define and understand his role. Other problems on the practical level refer to the communication process between laypersons and experts.

From the Swiss case study in this paper (PubliForum, 1999a), some experience and considerations in these fields are presented and reflected upon from theoretical and practical perspectives. Our general intention is to give hints, and to clarify criteria supporting a communication process founded in rational arguments that leads to an autonomous dialog of citizens about ethical aspects in the field. The main question is "What does the Swiss experience teach us about taking the role of lay people within democratic participation procedures seriously?" The short answer in general is "There must be an orientation for all members of a CC-process having clear rules and knowing their different roles that support transparency, credibility 
and fairness of the whole procedure and a 'good product': a substantial final document or citizens' report."3

\section{CASE STUDY: PUBLIFORUM}

The empirical basis of our analysis consisted of written documents, such as discussion papers, invitations, reports, as well as the final citizens' report (PubliForum, 1999a). Additionally, key informants, who had partaken in the arrangement and/or who had been at the conference itself, have been interviewed. One should be aware of the fact that the interviews have been taken in August 2004. That is about more than five years after the PubliForum GeneTechnology and Nutrition had been held. The persons, who have been interviewed were experts, members of the lay panel, of the advisory group and of the organizing institution. Each interview started with a general questionnaire concerning the $\mathrm{CC}$ procedure, the role of the laypersons, of experts, and of ethics. Each live interview in Switzerland lasted about $2 \mathrm{~h}$ and has been audiorecorded, then written down for further analysis.

The Swiss PubliForum Gene Technology and Nutrition in 1999 was organized by the Swiss Centre for Technology Assessment (TA-SWISS). The TA-SWISS was institutionalized by the Swiss Parliament as an attached institute to the Swiss Science and Technology Council in 1992. The PubliForum on gene technology and nutrition was the second PubliForum to be organized in Switzerland. Whereas in the first PubliForum, Electricity and Society (1998), attention focused on the development and implementation of a new participatory democratic instrument in Switzerland, the second conference Gene Technology and Nutrition (1999) could already concentrate more on the contents, although the issue in that period was rather delicate.

The second PubliForum about GM food has to be seen in context of a larger debate about human and non-human gene technology. This debate was initiated by the so-called "Beobachter-Initiative" ("observer initiative") in April 1987. This initiative led up to general frame legislation in the Swiss Constitution concerning the handling of gene technology (Art. 24novies SBV) in May 1992. From that time on, the Swiss Government was instructed to develop a legislation corpus concerning gene technology, the so-called "Gen-Lex." This law was to regulate in detail how the integrity/ dignity of the creation ${ }^{4}$ and the safety of men, animals, and the environment

\footnotetext{
${ }^{3}$ For an extensive analysis of further differences between listed criteria see Joss and Bellucci (2002) and Reber (2005).

4 "Würde der Kreatur."
} 
could be taken into account in the face of the new biotechnological developments.

In 1993, within this process the "Genschutz-Initiative" ("Gene-Protection-Initiative") started working for a prohibition on gene technology 5 (http://www.admin.ch/ch/f/pore/vi/vi240t.html) in Switzerland. The Swiss electorate rejected the initiative in a plebiscite in June 1998. The initiative failed, because - as interviewees judged the situation - the Swiss people saw chances in the field of human medical development, while they were not interested in or had even reservation against the development of gene technology in the field of agriculture and nutrition.

Against this background, the major aim of the PubliForum Gene Technology and Nutrition seemed to be to calm down a debate that had been stirring the blood of pro- and counter parties in the period before the plebiscite. The organizers perceived the PubliForum as a possibility or even an opportunity to face the citizens' feelings of unease towards gene technology and to continue a public debate that was initiated by the plebiscite (PubliForum, 1999a: 6). This PubliForum on GM-food was thus regarded as a political mediating means to reconcile science and citizens and to restore trust.

Retrospectively, the PubliForum was also recognized as a further grassroots democratic instrument in the political landscape of Switzerland that provided a more qualitative insight into the people's opinions than the mere quantitative instruments of referenda and polls.

In the beginning, the organizers expected a PubliForum mainly to be useful as an instrument helping laypersons to understand new technologies in order to support the public debate, or as an instrument that could inform decision-makers about people's attitudes. As a matter of consequence, the organizers named two addressees of the PubliForum: the public (with the help of the media) and political decision-makers. But the citizens' success in building a competent evaluation of complex technologically introduced problems demanded respect. Because of this, the lay panel finally recommended PubliFora as a consultative means to qualify political decisionmaking processes. This shift in evaluating the concept of PubliFora from an informative to a consultative understanding was less understood by the members of the expert panel.

Although the organizing team of TA-SWISS followed the Danish CCmodel when designing the PubliForum as a participatory instrument, there

\footnotetext{
${ }^{5}$ The claims of the initiative covered three aspects: First, prohibition of the release of genetically modified plants, second, prohibition of genetically modified animals, third, prohibition of patenting of genetically modified animals and plants. The Swiss electorate had just the choice of voting "yes" or "no." For further information see http://www.admin.ch/ch/f/pore/vi/ vi240t.html.
} 
are two major differences to the Danish example: First of all, the lay panel with about 30 participants is nearly double sized compared with ordinary lay panels in citizens' conferences of the other nations. The high number of laymen is due to the fact that Switzerland is a multilingual country. Therefore, the organizers tried to invite a significant number of citizens from every linguistic region of Switzerland, following the idea to proportionally take into account the size of each region. Because German- and Frenchspeaking participants dominated the Italian-speaking participants in numbers, the panel was held bilingual, in German and in French. The Swiss multilingual situation requires translators as a further element of citizens' conferences. Furthermore, it challenges the abilities of the facilitator, who has to ensure best communication conditions. These experiences of Swiss moderators have recently been used on the European level.

Secondly, the TA-SWISS staff and its accompanying committee decided to abandon the obligation of the lay panel to come up with a consensus as result of the citizens' debate, because even the word "consensus" is associated with negative connotations in the public. The reason for this can be found in the Swiss political system, which is a so-called concordancedemocracy, not a representative democracy, in which majorities of the political parties are decisive. The Swiss democratic system is based on "consensual" decisions that are achieved by integrating all relevant forces of the society within the decision-making processes to ensure the execution of political decisions. Thus, Swiss people are suspicious about the word "consensus." In order to increase interest in the participatory process of a citizens' conference, the obligation of producing a consensual paper was dropped and the type of participatory arrangement was not called "consensus conference," as in Denmark, but "PubliForum." This new name was introduced to indicate that consensus should not be presupposed, different perspectives would be tolerated, and dissent would be allowed. One interviewee from the accompanying committee considered it a quality criterion of the PubliForum that a majority and a minority vote and the ways of argumentation are made transparent for political counseling.

In general, the arrangement of the Swiss PubliForum followed that of the Danish model. Similar to the other Swiss PubliFora, the first organizational step of the PubliForum Gene Technology and Nutrition was to establish the accompanying committee and the citizens' panel. The TASwiss management and the organizing committee from the TA-SWISS office fulfilled this task. They also organized a professional facilitator and the

\footnotetext{
${ }^{6}$ Obviously, the term consensus as it is used in Switzerland in fact means compromise and the suspicion directed against "consensus" as a basis for politics means is directed against solutions that integrate all interests by compromise.
} 
translators. The citizens' panel consisted of 28 participants representative in age, profession, gender, and lingual region.

The accompanying committee consisted of representatives of industry, science, administration, media, policy, and NGOs. They had to prepare fact sheets, which served the members of the citizens' panel as a means to familiarize themselves with the issue at stake. With regard to this task, the accompanying committee had to guarantee the well-balanced nature of the fact sheets and had to assist the citizens with finding suitable experts. Additionally, the accompanying committee had to look for referees being able to help it in these tasks. The instructors had to be neutral with respect to the issue and they had to have pedagogical talents to present sufficient information in a lay-friendly form.

About 230 persons - from science, industry, politics, administrations, and NGOs - had been asked by the TA-SWISS office whether they would be willing to take part in this PubliForum as experts. Out of 79 persons, who declared to be willing, the citizens' panel selected 18 as experts (informants) with the assistance of the accompanying committee.

One important result from the interviews was that the assistance of the accompanying committee is a rather sensitive element in the whole process of a PubliForum, especially with regard to the claim of balanced or neutral information, both about the topic and about the experts. Within the accompanying committee, there was a temptation to influence the citizens by means of the information given with the fact sheets as well as in the way "experts" were profiled. In some interviews, it was mentioned that there had been quarrels between the members of the accompanying committee even about the fact sheets. As a result, the idea of neutral information was dropped and pro- and counterpart information sheets were presented. The advantage of this approach was that the participants quickly came to understand the controversial problems and evaluative implications of the issue.

Some of the members of the accompanying committee were deeply engaged in the issue gene technology and nutrition and they found it hard to retreat from the citizens, letting them find their own judgments. Some members of the accompanying committee, representing the involved industry, obviously tried to "enlighten" special participants who seemed not to agree with their desired viewpoint, using, e.g., their opportunity of common meals during the preparation weekends for this purpose. But the members of the accompanying committee, who had been interviewed, reported the impression that the attempted manipulations evoked a counter effect among the lay participants. The citizens seemed to know how to save their independence and sovereignty. 
The citizens' panel was prepared and assisted with fact sheets, additional articles from newspapers, magazines, etc., and two preparatory weekends. On the first weekend, the citizens had to acquaint themselves with each other to form a group. Furthermore, they came in touch with the process and milestones of a PubliForum and were introduced to the topic with the help of three lectures held by invited referees. Then they had to determine subject areas they were particularly interested in and to form subject-centered subgroups. On the second weekend, the citizens' group had to fix a catalog of particular questions and to select those experts who were invited to answer their questions on the conference weekend. The conference consisted of two hearing days on which the selected experts (forming panels themselves, which implies special dynamics) had to answer the citizens' prepared questions and to go into discussions with them. On the third day, the citizens wrote the final report, which was presented to the public the following day. During the process, the facilitator and the translators had to give assistance in order to guarantee a good communication process. ${ }^{7}$ The final citizens' report offered presentations of each question and the answers, the judgments of the citizens divided in majority vote and minority vote, and differentiated recommendations to every single question. The report ended with a conclusion and a final recommendation based on the majority vote. The panel agreed not to publish the fairly short ratio of the vote (13: 15 under the 28 participants of the citizens' panel). But at the presentation of the citizens' report to the public (PubliForum, 1999b), one of the participants violated the agreement and gave the final vote's ratio away, an act that caused much annoyance in the citizens' panel. ${ }^{8}$

\section{THE LAY PERSONS IN ACTION}

The very core of consensus conferences is the discursive process, leading to the citizens' judgment, which follows the encounter of lay panel and experts' panel. Since central aspects in the concept of CCs are ethically relevant and CCs result in a final document, consisting of normative and evaluative statements (Skorupinski and Ott, 2002), the focus of our analysis was on the following three relations: (a) Lay persons as moral subjects, (b) Lay persons and experts, (c) Lay persons and facilitator.

\footnotetext{
${ }^{7}$ This second PubliForum about GM foods seemed to have challenged the facilitator more than the first Swiss PubliForum on energy affairs (Egger, 2000: 18).

${ }^{8}$ This event, often mentioned in the interviews, might reflect the Swiss sensitiveness regarding "consensus."
} 


\subsection{Lay Persons as Moral Subjects}

A comparative study on nine citizens' conferences on gene technology issues shows that the Swiss panel was the most outstanding one with regard to the variety of subject areas (Schwab, 2000). ${ }^{9}$

Ethical arguments played an explicit and important role in the Swiss conference as often mentioned in the interviews, in the media and in the literature. This underlines the role of the lay persons as moral subjects and the role of the participatory TA-arrangements as an instrument to render transparent reflections about values and norms in a society for political decision-makers and for the ongoing debate in society.

While the majority of the citizens' panel excluded the job argument ${ }^{10}$ as an ethical argument (PubliForum, 1999a: 34), they denied a research prohibition, but recommended a moratorium for the production and marketing of genetically modified organisms. They justified ongoing risk research on the one hand. On the other hand, the moratorium for the production and marketing of GMO underlined the recommendation that Switzerland should blaze the trail for an international GMO-legislation (PubliForum, 1999a: 46).

Ethical reasons for the development of gene technology in agriculture and nutrition would have been accepted, if the technology had provided any use for solving the nutrition problems of the Third World and if there were no other way. It would not be acceptable as a replacement of traditional or local food production, but as a complement. Normative terms like justice and fairness, values like solidarity are the key words in relation to developing countries (PubliForum, 1999a: 34f.). The citizens' interests in global solidarity show them as citoyens who think about the common good not only in national, but also in international terms and leave the standpoint of an egocentric bourgeois perspective. ${ }^{11}$

Prudential ethical arguments were brought forward with respect to, e.g., risk assessment, or the ecological equilibrium as well as misgivings concerning the integrity/dignity of natural entities (PubliForum, 1999a: 34).

\footnotetext{
${ }^{9}$ The Swiss panel dealt with questions concerning health (allergies, resistance to antibiotics) and environmental impacts (biodiversity, organic farming), private and public research, ethics, economy (monopolies), international perspectives, public affairs like consumer interests, labeling, the use of gene food, patent questions, developing countries (loss of independence, social justice, economic fairness, terminator technology), legislation in a local and global perspective, and considerations on Swiss single-handed efforts.

${ }^{10}$ Schwab (2000) remarks, as a Swiss speciality, the fear for loosing jobs when Switzerland would refuse gene technology as well as the reflection about possible consequences for Switzerland as a research location.

11 This change of perspective and its role for the estimation of the discursive process in the evaluative and normative dimension is explained in Skorupinski and Ott (2002).
} 
Furthermore, the citizens remarkably often pointed out the necessity of long time monitoring and risk research and stressed the - normative - right of health protection. Here, the recommendation of the moratorium was settled, which says that production and marketing should be forbidden, but that, especially, public research should continue. In this context, questions of responsibility and precaution are touched.

Another ethical dimension could be experienced especially in the interviews, a perspective that is fixed neither in the final report nor in the papers about this conference, and that cannot be found in the questionnaires. Nevertheless, as all interviewees agreed, this dimension of personal sincerity and credibility seemed to be quite important for the citizens' opinion forming process and the lay-expert-relationship.

\subsection{Lay Persons and Experts}

The citizens' panel selected 18 experts from a list of 79 persons, who had been briefly profiled by the accompanying committee. Onto the experts' panel were elected four representatives of NGOs, three from the industry, seven scientists from universities or public research institutes (one of them was an ethicist), one politician, one administration person, one physician, and one law expert. One expert was asked twice about two different issues. All interviewees regarded the experts' panel as being well balanced with regard to its composition. This judgment does not imply that the citizens or the interviewees had been satisfied with the way each expert performed her or his task. Especially the ethicist was blamed for not having found an adequate approach to the issue.

As already mentioned, there is a range of expectations of what a PubliForum should or could be, for instance on the procedural level. This spectrum influences how the relation between the citizens' panel and the expert panel is conceived, especially if the participants are seen as citizens with active political counseling tasks or as laypersons who representatively illustrate how opinions could be formed through informational processes.

The interview answers concerning the primary aim of the conference show that this strongly relates to the conception of what is/makes up an expert and how the relation between experts and laymen is seen. If there is strong confidence in the autonomous capabilities of the citizen panel to elaborate on a competent judgment, the citizens' report will be as highly estimated for political counseling as expert opinions. Both are viewed as complementary instruments. But if there is a predominant belief in sciences as the "only truth," the bigger will be the adoration of experts from whom the "normal" citizens can only learn how things really function. The only 
thing such experts might learn from the citizens is about their fears in order to learn how to enlighten laymen about the irrationality of citizens' worries.

Some interviewees complained about the manipulative power of such fuzzy concepts like what is an expert. They suggested sharpening the awareness of the concept of an expert within the citizens' panel as well as within the experts' panel. One should be aware that scientific experts aren't experts for questions they have not done any research on, suggested some interviewees. Everybody is an expert only for a small range of experience. Especially the expert interviewee pointed out the difficulty of distinguishing between fact and hidden values because every fact needs interpretation. ${ }^{12}$ Certainly everybody is an expert in questions of moral decision-making, at least from the point of view of an autonomous concept of moral agents as for instance proposed in participatory processes founded in a Habermasian approach. In this context, it is worth mentioning that, already in the preparatory phase of the PubliForum, it was decided to speak of "informants" ("Auskunftspersonen") instead of "experts," as some interviewees underlined.

All interview partners mentioned as a remarkable ethical dimension of the expert-lay-relation the citizens' interest in the experts' personal integrity and his or her personal attitude towards the discussed conflicts. Since scientists are not familiar with being asked that sort of questions, it happened that an expert complained about the citizens asking the "wrong questions" and that they should learn to ask the "right questions." That event left a lasting impression on all participants.

Some interviewees pointed out the relevance of the interrelationship between experts on the experts' panel. Quarrels between experts are not only evoked by differences in the interpretation of facts, but also by different selfimages. If experts restrained themselves to the issues they really do research on, which means acting as an expert "in a good sense of the word," they would be in danger of not leaving deep impressions on the lay panel. Those experts who obviously "trespassed their expert's competence" (this was a statement of an expert about another expert) were often more effective. This presents another big challenge for the facilitator during the hearings, when a productive and fair communication is to be guaranteed.

\subsection{Lay Persons and Facilitator}

Nevertheless, the facilitator seems to be at least as influential on the selfconcept of the participants as the organizers and the accompanying committee (Egger, 2000). To a great extent, it depends on the facilitator to

\footnotetext{
${ }^{12}$ The expert interviewee reported the behavior of some of the fellow experts as dishonest, since they gave strong recommendations about how the lay panel has to assess the topics at stake.
} 
establish a creative, fair, and respectful communication atmosphere that offers the participants a frame to realize themselves as autonomous agents. From the beginning the function of political counseling had been intended by the organizers, although they started with doubts about the realization. Due to the stirred up public debate, the citizen participants were anxious and alert to save their independence and autonomy during the whole process.

At this point, it is useful to mention some other aspects concerning the relation between lay persons and the facilitator, who is called "mediator" in the Swiss PubliForum, especially from the perspective of the facilitator himself (Egger, 2000). He defined his role as "mediator with the task of moderation" (Egger, 2000: 2). To guarantee procedural justice, the TA advisory team defined his role as guarantee of communication by means of a "genuine dialogue," taking care that there is an understanding for the different value systems within the lay panel, that these perceptions should not be valued by each other (Egger, 2000: 5). In general, the mediator had to be neutral, both concerning the content of the topic and concerning the procedures of the consensus conference, and had to take care that experts respected lay opinions. Furthermore, besides neutrality, social competence, emotional intelligence, competence in the topic, a natural modesty, the ability for permanent learning, to be self-critical were listed as essential qualities of the facilitator (Egger, 2000: 9). Problems are admitted with respect to making clear his own intentions during communication. Sometimes he did not have the overview concerning the consistence of the decision making process and he had problems of guaranteeing the formal procedure having more time for important questions in the field of the topic or he is missing his leadership (Egger, 2000: 17).

The role definition of the mediator changed from the first to the second PubliForum. The first task for the mediator in the first PubliForum was, besides neutrality, to be the "speaker of the lay panel in view of the organizer and the public observers." But on the second PubliForum, this task was changed as now being the "connection between the citizens' panel and the organizer." (Egger, 2000: 21 and 24)

\section{SOME THEORETICAL REFLECTIONS}

The general analysis of the literature and the concrete empirical analysis of the Swiss CC case PubliForum show that there are several tensions between theory and practice. Problems exist on different levels, concerning the general rules and the specific roles within the $\mathrm{CC}$ procedure. When starting a $\mathrm{CC}$, it seems to be very important to define and to explain clearly the rules and roles to all involved participants, especially the lay people, the experts, 
and the facilitator, and to keep these rules and roles consistent during the process. A detailed concept for participatory arrangements in the context of political counseling, e.g., in CCs, has been developed by Skorupinski and Ott $(2000,2002)$. In this concept, the very center of discursive opinionforming is the process of argumentation, of verifying arguments in the dimension of facts and in the dimension of norms and values and to weigh arguments in a consensus-oriented manner, which does not mean that there is an obligation for ending up with consensus. The discursive setting necessitates the participants to leave the standpoint of the "bourgeois"-role, emphasizing personal interests and property, and to take the standpoint of the "citizen"-role, being oriented to the common welfare, i.e., taking a moral point of view. If this role is guaranteed by the rules of the CCprocedure, their results and recommendations can claim to be ethically justified with increasing validity, the more the conditions of their arrangements approximate to the ideal conditions of normative discourse. Within the limitations of this paper it is not possible to get deeper into the analysis of the real discursive processes at the conference. ${ }^{13}$

Furthermore, concerning the role of lay people, it is necessary to emphasize that they are the main free agents within this participatory process and that their autonomy has to be respected and protected by the organizers and the facilitator during the whole procedure. For the citizens' panel, the outstanding responsibility of being asked in the role of legitimate political counselors is a strong motive for their very serious work in this role, e.g., for disclaiming any attempt to manipulate them. Vice versa, the political mandate of the citizens' vote calls for politicians taking it seriously.

Concerning the experts, it is important to remember that their role is to give correct information about facts and problems concerning the topic. The role of an expert in ethics is to make clear basic positions within the field and not to give personal recommendations to the lay people, who are the main ethical actors in the CC. Thus, ethical experts do not introduce the moral point of view, but they reflect upon potential conflicts between several moral perspectives or ethical approaches. To invite only one ethical expert does not suffice. As in the case of scientific experts, counter-expertize is necessary, which means that at least two ethicists are necessary to give the lay panel an idea of ethical controversy. The plea for several ethicists takes into account that several ethical approaches do exist and that every ethicist prefers a specific ethical position to others. Therefore, the ethical experts should be encouraged to defend their own moral conviction in terms of their preference of a certain ethical approach instead of playing a neutral role.

\footnotetext{
${ }^{13}$ With respect to the relation between ideal discourses and real discursive pTA-arrangements see Skorupinski and Ott (2000: 43-45): "Participatory and discursive TA can be seen as possible application of discourse ethics."
} 
Nevertheless and furthermore, ethicists should also demonstrate how to argue with moral arguments, for instance, from a metaethical point of view, as it sometimes seems to be necessary if a so called naturalistic fallacy is involved in the argument.

Concerning the facilitator, it is important to mention that this difficult job has to guarantee procedural justice, respect for the rules, and correctness of the development of the arrangement. The facilitator has a rather demanding job, surveying and mediating all the communication within the citizens' panel as well as between the different groups. At the same time, he is asked to remain neutral. He is not allowed to contribute to the scope of arguments itself, but he is asked to intervene, for instance when participants present unclear arguments.

Analyzing case studies leads to questions present in the theoretical debate. In order to optimize discursive arrangements for public participation with respect to process and result - these arrangements need and deserve to be built on a solid theoretical foundation. The present paper tries to bring into focus more the role and opinions of the $\mathrm{CC}$ involved people. But further questions arise concerning the theoretical frame and the practice of CCs and will be subject to future investigations. ${ }^{14}$

\section{REFERENCES}

Böhler, D., M. Kettner, and G. Skirbekk (eds.) (2003), Reflexion und Verantwortung (Reflection and responsibility), Frankfurt a.M.: Suhrkamp.

Egger, U. (2000), Hinweise zur Rolle des Mediators beim PubliForum (Remarks concerning the role of the facilitator at the PubliForum), Dokument TA DT 27/ 2000, ed. Schweizerischer Wissenschafts- und Technologierat, Bern.

Frewer, L., J. Lassen, B. Kettlitz, J. Scholderer, V. Beekman, and K. G. Berdal (2004), "Societal Aspects of Genetically Modified Foods." Food and Chemical Toxicology, 42, pp. 1181-1193.

Habermas, J. (1996), "Drei normative Modelle der Demokratie (Three Normative Models of Democracy)," in J. Habermas (ed.), Die Einbeziehung des Anderen, Studien zur politischen Theorie, Frankfurt a.M: Suhrkamp, pp. 11-24.

Habermas, J. (2001), Die Zukunft der menschlichen Natur, Auf dem Weg zu einer liberalen Eugenik? (The Future of the Human Nature, on the Way to a Liberal Eugenics?), Frankfurt a M: Suhrkamp.

\footnotetext{
${ }^{14}$ Last, but not least, we would like to mention, that in this paper our intention was to learn more in general from the Swiss case study. Our intention was neither to criticize special experts, organizers, or even laymen nor to analyze sophisticated philosophical problems like naturalistic fallacies involved in the process of argumentation. For further analysis in this direction see Reber (2004).
} 
Heeger, R. and F. W. A. Brom (2003), "Ernährung, Verbraucher und Staat. (Nutrition, Consumer and State)," in M. Düwell and K. Steigleder (eds.), Bioethik, Eine Einführung, Frankfurt a. M: Suhrkamp, pp. 371-378.

Heinrich, H. (2005), "Partizipationsforschung und nachhaltige Entwicklung" (Participation research and sustainable development) and Gethmann, C. F. (2005), "Partizipation als Modus sozialer Selbstorganisation? Einige kritische Fragen." (Participation as a mode of social self-organization? Some critical questions.) GAIA $14 / 1$, pp. 30-33.

Joss, S. and S. Bellucci (eds.) (2002), Participatory Technology Assessment, European Perspectives, London: Centre for the Study of Democracy.

Korf, B. "Partizipation als Tyrannei?" (Participation as tyranny?) and Renn, O. (2005), "Partizipation - ein schillernder Begriff" (Participation - an ambiguous concept) GAIA 14/3, pp. 224-228.

Nielsen, A. P., B. Skorupinski, H. W. Ingensiep, H. Baranzke, J. Lassen, and P. Sandoe (2005), "Participatory Arrangements (WP2)," in V. Beekman (ed.), Development of Ethical Bio-Technology Assessment Tools for Agriculture and Food Production, Interim Report, The Hague: LEI, pp. 40-61.

PubliForum (1999a), Gentechnik und Ernährung 4.-7. Juni 1999 in Bern, Bericht des Bürgerpanels (Citizenś Report: Gene technology and nutrition) (TA-P/1999 d), Bern: Schweizer Wissenschaftsrat.

PubliForum (1999b), Gentechnik und Ernährung, Medienspiegel Oktober 1999 (Gene technology and nutrition, mirror of media), Bern: TA-Swiss.

Reber, B. (2004), "Ethique et évaluation technologique participative," in B. Castagna, S. Gallais, P. Ricaud, and J.-P. Roy (eds.), La situation délibérative dans le débat public2, Tours: Presses Universitaires François Rabelais, pp. 387405.

Reber, B. (2005), "Technologies et débat démocratique en Europe.” Revue Française de Science Politique, 55, pp. 811-833.

Schwab, F. (2000), Konsens-Konferenzen über Genfood, Ist das PubliForum der Schweiz ein Sonderfall? (Consensus conferences about gene food - Is the Swiss PubliForum a special case?) Bern.

Skorupinski, B. and K. Ott (2000), Technikfolgenabschätzung und Ethik, Eine Verhältnisbestimmung in Theorie und Praxis (Technology assessment and ethics determining a relationship in theory and practice), Zürich: Hochschulverlag AG an der ETH.

Skorupinski, B. and K. Ott (eds (2001), Ethik und Technikfolgenabschätzung, Beiträge zu einem schwierigen Verhältnis (Ethics and Technology-assessment, Contributions to a Difficult Relation), Ökologie und Gesellschaft Bd. 16, Basel, Genf, München: Helbing \& Lichtenhahn.

Skorupinski, B. and K. Ott (2002), "Technology Assessment and Ethics - Determining a Relationship in Theory and Practice." Poiesis \& Praxis, International Journal of Technology Assessment and Ethics of Science, 1, pp. 95-122.

Skorupinski, B. (2003), "Novel Food - Ethische Perspektiven (Novel food - ethical perspectives)," in M. Düwell and K. Steigleder (eds.), Bioethik, Eine Einführung, Frankfurt a.M: Suhrkamp, pp. 379-387.

Smith, G. (2003), Deliberative Democracy and the Environment, London/New York: Routledge. 
Zittel, T. (2003), "Participatory Democracy and Political Participation." Paper presented to the Joint Sessions of Workshops of the European Consortium of Political Research, Edinburgh (Workshop: Bringing the Citizens back in participatory democracy and political participation) $16 \mathrm{p}$.

Barbara Skorupinski

Unit für Ethics in Biosciences

University of Basel

Missionsstr. 24, 4056 Basel

Switzerland

E-mail: malibask@bluewin.ch

Heike Baranzke

Moraltheologisches Seminar

Rheinische Friedrich-Wilhelms-Universität Bonn

Am Hof 1, 53113 Bonn

Germany

E-mail:heike.baranzke@t-online.de

Hans Werner Ingensiep and Marc Meinhardt

Universität Duisburg-Essen

Institut für Philosophie

Universitätsstr. 12, 45117 Essen

Germany

E-mail:h.w.ingensiep@uni-essen.de 